\title{
Selected Reference Books of 1993
}

\section{Eileen McIlvaine}

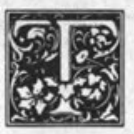

his article follows the pattern set by the semiannual series initiated by the late Constance $\mathrm{M}$. Winchell more than thirty years ago and continued by Eugene P. Sheehy. Because the purpose of the list is to present a selection of recent scholarly and general works of interest to reference workers in university libraries, it does not pretend to be either well balanced or comprehensive. A brief roundup of new editions of standard works is provided at the end of the article. Code numbers (such as AD540 and CJ251) have been used to refer to titles in the Guide to Reference Books, 10th ed. (Chicago: ALA, 1986) and the Supplement ... Covering Materials from 1985-1990 (Chicago: ALA, 1992).

\section{ENGLISH LANGUAGE}

Berg, Donna Lee. A Guide to the Oxford English Dictionary. Oxford and New York: Oxford Univ. Pr., 1993. 206p. $\$ 19.95$ (ISBN 0-19-869179-3). LC 9141383.

The author, who is affiliated with the Centre for the New Oxford English Dictionary and Text Research at the University of Waterloo (the body responsible for computerizing the second edition of the $O E D$ ), has written this handbook to guide users, both scholarly and casual, through the printed OED (Guide AD27AD28, Suppl. AD6). The first half of the book describes the various parts of a typical dictionary entry as the reader would encounter them: headword, pronunciation, part of speech, etymology, definition, quotations, etc., with many examples from the dictionary (presumably from the second edition, but this is not specified).

Part II, "A Companion to the OED," is essentially an encyclopedia with one-totwo paragraph entries defining the terms and identifying the people and institutions associated with them. It is unfortunate, given the author's affiliation with the University of Waterloo, that the computerized versions of the $O E D$ are ignored; even the term lemma, which caused so much confusion for users of the CD-ROM version of the first edition, is not defined. And nowhere is there any discussion of the differences between the first and second editions. Frequent users of the $O E D$ should read the extensive comparison of the two editions which appeared in the Review of English Studies, n.s.41:76-88 (Feb. 1990).

This guide should be useful in answering questions about OED entries and libraries will want to have it; however it is not all-you-ever-wanted-toknow-about-the OED.-M.C.

\section{BIOGRAPHY}

Ackerl, Isabella, and Friedrich Weissensteiner. Österreichisches Personen Lexikon. Wien: Ueberreuter, 1992. 552p. ÖS497 (ISBN 3-8000-3464-6). LC 93-116283.

Öesterreichisches Personen Lexikon provides brief (one or two paragraphs) biographical entries for Austrians, living and dead, who have played a role in the cultural, political, or intellectual milieu from 1918 to the present (no Hitler, though). The entries, some with photographs, include brief biographical infor-

Eileen McIlvaine is Head of Reference and Collections, Butler Library, Columbia University, New York, New York 10027. Although it appears under a byline, this list is a project of the Reference Departments of Columbia University Libraries, and notes are signed with the initials of one of the following staff members: Paula Gabbard, Katherine A. Keller, Barbara Sykes-Austin, Avery Library; James L. Coen, Business Library; Mary Cargill, Olha della Cava, Robert H. Scott, Sarah Spurgin, and Junko Stuveras, Butler Library. 
mation and in many cases references to other sources. Although much of this information is available in other sources, this is a very useful single-volume compilation, especially rich in cultural figures. -M.C.

\section{Victorian Biography: AChecklist of Contem-} porary Biographies of British Men $\mathcal{E}$ Women Dying between 1851 and 1901. Compiled by Peter Bell. Edinburgh: Peter Bell (Bookseller), 1993. 193p. (ISBN 1-871538114).

This checklist of contemporary biographies of British men and women who died between 1851 and 1901 was compiled in order to facilitate the work of scholars interested in researching individuals living in the Victorian era. It goes beyond the "greats," to include the "far from great" (Pref.) and cites biographical material, however minor, which might prove to be of use to scholars.

Working in a field already rich in biographical sources, Peter Bell, the compiler, has tapped existing sources, such as Frederic Boase's Modern English Biography Containing Many Thousand Concise Memoirs of Persons Who Have Died between the Years 1851-1900 (Guide AJ222), for his material, while being careful not to duplicate them.

The result is a compilation that briefly identifies over 2,000 English, Scottish, Welsh, and Irish men and 400 women who died between 1851 and 1901 and cites references to one or more biographical works published within a short period of the subject's death. Most of the works cited are either biographies, memoirs, reminiscences, or recollections, many written by family members and printed for private circulation. Where possible, the citations include verification information in library catalogs. Excluded from this compilation are autobiographies and diaries, as these are already well covered in such works as William Matthews' British Autobiographies: An Annotated Bibliography of British Autobiographies Published or Written before 1951 (Guide AJ239), and his British Diaries: An Annotated Bibliography of British Diaries Written between 1442 and 1942
(Guide BD672), and in John Burnett's The Autobiography of the Working Class: An Annotated Critical Bibliography (Guide $\mathrm{CH} 648$, Suppl. $\mathrm{CH} 270$ ). Nor does it include funeral sermons and memoirs prefixing literary works.

Clearly this compilation has its niche and within that niche it fulfills its stated purpose well.-O.d.C.

\section{PHILOSOPHY}

Fetzer, James H., and Robert F. Almeder. Glossary of Epistemology/Philosophy of Science. New York: Paragon House, 1993. 149p. \$17.95 (ISBN 1-55778-5589). LC 92-22762.

There are many things to commend this little glossary: it is selective, it explains concepts rather than defining words, and it uses plain English rather than scholarly jargon.

The glossary limits itself to about 300 terms and twenty or so individuals - key concepts and persons in the study of the nature of knowledge. It explains each term in a context of related terms: "Knowing that vs. knowing how" and "Historical possibility/necessity/impossibility" are typical entries. Rather than attempting to trace the origins of these concepts, the compilers have contented themselves in simply presenting them as they are currently understood by scholars working on philosophical problems.

As these concepts are not simple, this glossary, besides enlightening the curious layman, can serve as an invaluable reference tool for students and teachers of courses in epistemology and the philosophy of science.-O.d.C.

\section{MYTHOLOGY}

Reid, Jane Davidson. The Oxford Guide to Classical Mythology in the Arts, 13001990s. New York: Oxford Univ. Pr., 1993. 2 vols. (1310p.) \$195 (ISBN 0-19504998-5). LC 92-335374.

Inspired by Andor Pigler's Barockthemen: eine Auswahl von Verzeichnissen zur Ikonographie des 17. und 18. Jahrhunderts (Guide BE195), Jane Davidson Reid has taken on an even more ambitious project: to compile a dictionary of Greek and Roman mythology listing in chronological 
order (from 1300 to the 1990s) mythological characters and stories as they appear in the arts, including painting, sculpture, classical music, dance, and literature. Film is only included if it is a revision of an already cited work by the same artist, as in Jean Cocteau's Orphée. (Marcel Camus' celebrated Brazilian film Black Orpheus, for example, is not included.) Reid has tried to be as exhaustive as possible, realizing from the start the quixotic nature of such a project. She immediately warns the reader that she did not incorporate Pigler into her work because it would be redundant and points out that incorporating the standard print catalogs, like Bartsch, Le Peintre graveur and its Supplements (Guide $\mathrm{BE} 363)$ was not possible given her publication deadline. This work recalls Herbert Hunger's Lexikon der griechischen und römischen Mythologie, mit Hinweisen auf das Fortwirken antiker Stoffe und Motive in der bildenden Kunst, Literatur und Musik des Abendlandes bis zur Gegenwart (Guide CF29), but it is more exhaustive, more current, and has a 191-page index of all artists cited.

Reid explains in her Introduction that she chose to use Greek names of classical gods and goddesses with cross-references from Roman to Greek, and she points out the differences between similar Greek and Roman deities within each entry. A brief description of the myth begins every entry and is followed by the major classical sources for the subject. Selective citations for further reading are often included. Reid frequently divides an entry into subentries: for example, the entry for Aphrodite has the subentries "General List," "Birth of Aphrodite," "Cythera," "Isle of Aphrodite," "Aphrodite and Anchises," "Girdle of Aphrodite," "Worship of Venus," "Venus Frigida," "Venus and Satyrs," "Statue of Venus," and "Tannhäuser and the Venusberg." Obviously, some subentries have no classical source but are widely depicted postclassical themes. "See also" references appear prior to the list of artworks. Each citation of an individual artwork provides the birth and death dates of the artist, the title of the work, its genre or medium, the date of the work, and where appropriate, performance data, publisher, location of work, versions, revisions, other works related to the original, and source references. It is unfortunate that sound recordings are not cited.

Jane Davidson Reid has compiled an immensely valuable resource for all scholars interested in postclassical depictions of classical subjects. -P.G.

\section{LITERATURE}

\section{Dictionary of British Literary Characters.}

Edited by John R. Greenfield. New

York: Facts on File, 1993. Vol. 1. 655p.

$\$ 50$ (ISBN 0-8160-2178-3). LC 90-3998.

(In progress; to be in 2 vols., \$95.)

The first volume, subtitled 18th and 19th Century Novels, is an alphabetical list of characters in novels by authors whose important work appeared before 1890 (so that Hardy and Kipling appear in Volume 1); Volume 2 (forthcoming) will be subtitled 20th Century Novels.

The characters in Volume 1, all 11,663 of them from 486 novels, include a brief description of their role in the novel. There is an index of characters arranged by author, then title. The novels analyzed include all those by major writers, as well as representative examples of more unfamiliar authors; the compilers have consciously tried to include works by women writers. The novels have been exhaustively mined for characters, almost to the point of uselessness in some cases. Chrysal: or, The Adventures of a Guinea by Charles Johnstone, for example, accounts for some 175 entries, with such characters as Author, Bishop, Lord - Rake, etc. Looking through the characters included for Emma, a novel I have read many times, I see names I don't recognize; there seems to be much unnecessary padding.

In fact, it is hard to know who might need this book. The main characters of the major novels are listed in other character indexes, and brief plot summaries are available in various guides, as well as the inevitable Masterplots (Guide BD74, BD75, Suppl. BD97). Unless, of course, someone wants to know about 
the character "Puppy" from Alice in Wonderland, in which case this book will come in handy.-M.C.

Hopster, Norbert and Petra Josting. Literaturlenkung im Dritten Reich: eine Bibliographie. Hildesheim and New York: G. Olms, 1993. Vol. 1, 500p. DM 138 (ISBN 3-487-09686-2). (In progress; to be in 2 vols.) LC 93-222833.

Volume 1 of this outstanding and imaginative bibliography of the literary climate of the Third Reich is divided into two parts. The first is a bibliography of material written during 1933-45; the second, smaller half, lists scholarly studies, including dissertations, written after 1945.

Sources appear to have been thoroughly examined (despite the modesty of the Introduction), and the researcher can find references to subjects as varied as book production, lending libraries, theater productions, textbooks, popular literature, as well as to more formal literary criticism written in Germany between 1933 and 1945. Especially impressive is the detailed list, including locations and record group numbers, of archival holdings related to publishing in the Third Reich, including official records on censorship, propaganda, etc.

The bibliography has a detailed, though somewhat confused, classified arrangement. If a researcher, for instance, were interested in drama in the Third Reich, he would find material in the section (1) "Literaturkritik-Rezeption der deutschen Gegenwartsliteratur-Dramatische Formen" (this includes a citation to an annual listing of productions); (2) the section "Ideologisierung der Literature-Programmatik/Theorie-Dramatische Formen," and (3) the section "Literaturgeschichte, allgemein-Dramatische Formen," in addition to references to post-1945 studies located only through the subject index (which does not refer to the 1933-45 entries-these I found looking through the detailed Table of Contents). But the effort is well worthwhile, and researchers interested in the culture of Nazi Germany would do well to begin with this indispensable bibliography.
Volume 2 will be an annotated list of bibliographies of bibliographies and of book catalogs and lists. -M.C.

Jackson, J. R. de J. Romantic Poetry by Women: A Bibliography, 1770-1835. Oxford: Clarendon Pr., 1993. 484p. $\$ 72$ (ISBN 0-19-811239-4). LC 92-35190.

Readers sometimes come to the reference desk with the assignment to locate a women writer who has not been collected in a modern anthology and argue for her inclusion in future anthologies. These readers, as well as those engaged in upper-level and graduate research on the English Romantic period, will be well served by this bibliography listing the printed volumes of verse of nearly 900 women writers. The bibliography is arranged alphabetically by writer, and each entry provides a brief biography of the author before listing chronologically all of her books having at least seven pages and published between 1770 and 1835. Entries include publisher, date, dimensions of the title page, pagination, author as given on the title page, and the reference on which the entry is based. Verse translations into English are also included. Separate indexes list authors, titles, and publishers, by name and location. A chart showing the annual rate of production of all editions and first editions, with a graph demonstrating the phenomenal surge in publication in 1808 , complete the bibliography. Although there is no chronological index, many, but not all, of the authors are included in Jackson's Annals of English Verse 1770-1835 (Suppl. BD243). Recommended to all librariessupporting research in English and American literature. - S.S.

\section{CINEMA}

Art on Screen: A Directory of Films and Videos about the Visual Arts. Compiled and edited by the Program for Art on Film, Nadine Covert, editor. New York: Program for Art on Film; Boston: G.K. Hall, [1991]. 283p., 32p. of plates. $\$ 65$ (ISBN 0-8161-7294-3). LC 9134548.

As the Preface indicates, this directory contains 914 films and video titles culled 
from the 17,000 entries in the Art on Film computer database. Compiled by the Program for Art on Film, a joint venture of the Metropolitan Museum of Art and the J. Paul Getty Trust, the database provides detailed information about international film and video productions covering the fine arts (painting, drawing, sculpture), architecture, archaeology, photography, decorative arts, and related topics. To obtain information from the database, researchers may apply directly to the Program for Art on Film.

This directory is intended as a guide for film programmers, librarians, educators, art historians, and filmgoers who are concerned with the making or use of audiovisual programs on the visual arts. The art lover could also use this directory as a guide to the array of videos on art which are now available. In addition to the directory, Art on Screen includes five essays to provide context for the individual film listings and to stimulate thinking about the issues concerning the presentation of art on film. A filmography and a directory of resources for film programmers are included.

The work is intended to continue two out-of-print directories: the 1977 Films on Art, compiled and edited by the $\mathrm{Ca}$ nadian Centre for Films on Art for the American Federation of Arts , published by Watson-Guptill; and the 1952 Films on Art, edited by William M. K. Chapman, published by the American Federation of Arts. A third directory that may be of interest to this audience is From Museums, Galleries and Studios: A Guide to Artists on Film and Tape (Suppl. BE76).

Art on Screen is arranged in two sections: Documentaries with 709 entries and Features with 205 . The preface outlines the following selection criteria for the Documentary section: films and videos released between late 1975 and 1990 that are in distribution in the United States and have been favorably reviewed by the Program for Art on Film staff, or by evaluation panels, or recommended by advisory panels, or honored by film festivals. Art on Screen is aimed at an adult audience. Films and videos on photography are excluded because they are covered by Films and Videos on Photography, published in 1990 by the Program for Art on Film. Architecture and landscape architecture will be treated in Architecture on Screen announced for spring 1994. Arrangement of both sections is alphabetical by title, usually in English unless the work is better known by its original title. Each annotated listing includes the following components: title, series title, running time, color, format, date(s), country, language, edition/version, producing agency, credits (producer, director, executive producer, writer, camera, art consultant, and, for the Features sections, cast), distributor, synopsis, evaluation, comments (by the staff of the Program for Art on Film or the Metropolitan Museum's Media Center), reviews, and awards.

The indexes include a separate subject index for each of the two sections, Features and Documentaries, director index for the Features section, name index (artists, critics, art historians, and others who figure prominently) for both sections; series title index with individual titles listed under each series title; and a source index with names, addresses, and phone/fax number of distributors.

Despite weaknesses such as the typefaces and design, the inexplicable lack of a director index for documentaries and of birth and death dates for names, and inconsistency in the use of headings in the listings, Art on Screen provides essential information for large public libraries and film and art collections.-K.A.K.

\section{ARCHITECTURE}

Curl, James Stevens. Encyclopaedia of Architectural Terms, with Illustrations by the Author and John J. Sambrook. London: Donhead, 1993 (1992). 352p. il. $£ 45$ (ISBN 1-873394-04-7).

There are a great many encyclopedias, dictionaries, and glossaries of architecture and its vocabulary to choose from, varying in scope or generality, size, historical coverage, and intended audience (Guide BE258-BD277, Suppl. BE122$B E 124)$. This latest example most resembles the works of Cyril M. Harris in his 
Dictionary of Architecture and Construction (Guide BE266, 2d ed. 1993), and his Historic Architecture Sourcebook (Guide BE269) in their line drawings and concise definitions; Jill Lever's and John Harris' Illustrated Glossary of Architecture 850-1830 (Guide BE267) and Curl's earlier English Architecture: An Illustrated Glossary (Guide BE262, 2d rev. ed. 1986) for their coverage of British architectural terms, the subject of this work.

The Encyclopaedia of Architectural Terms offers 348 pages of definitions ranging from two words to four pages in length, with line drawings or photographs on almost every page. All examples are from British buildings, which makes this often dense work one most suited to specialized collections. A four-page select bibliography follows the glossary and supplements the works cited in the Preface.

The contents can often be very detailed; e.g., the term Symbol has 19 columns of hagiological symbols represented in and on churches and other buildings. Styles, such as Gothic, Gothick, and Gothic Revival are both described and illustrated, again in a British context. Building materials, ornamental details, elements, building types, and physical attributes are covered. The definitions are often thick with cross-references, signalled by arrows, which can make comprehension difficult. In other instances more guidance on locating the illustration of a built form is needed than an entry provides (e.g., the definition is under hip-roof but the illustration is under roof). There are no biographical entries; for these the author refers the reader to Colvin's Biographical Dictionary of British Architects 1600-1840 (Guide BE294), again reflecting the British focus of the work. The book will be of most use to the serious scholar of British, European, and Classical architectural history -B.S.-A.

\section{WOMEN'S STUDIES}

Encyclopedia of Childbearing: Critical Perspectives. Edited by Barbara Katz Rothman. Phoenix: Oryx, 1993. 446p. $\$ 74.50$ (ISBN 0-89774-648-1). LC 92-14975.

This useful interdisciplinary encyclopedia treats some 250 topics related to childbearing. Entries are well-written, with a strong feminist orientation. Topics range from discussions of childbearing in different countries, to feminist analyses of motherhood, explanations of medical procedures and drugs, and presentation of a variety of statistics. Although the majority of entries refer to issues relating to contemporary childbirth in the United States, entries also discuss goddess imagery, the language of birth, childbirth in science fiction, biblical and Talmudic images of pregnancy, and histories of all aspects of childbirth. Each signed entry includes a selective scholarly (three to ten items) bibliography of additional references. Arranged alphabetically with cross references and a good subject index. Recommended for all libraries supporting research on women, in spite of the fact that the encyclopedia chooses to sidestep the issue of surrogate motherhood, while including entries on open, closed, intercountry, and transracial adoption; birthmothers; and induced lactation. - S.S.

The History of Women and Science, Health and Technology: A Bibliographic Guide to the Professions and the Disciplines. Edited by Phyllis Holman Weisbard and Rima D. Apple. $2 d$ ed. Madison, Wisc.: Univ. of Wisconsin System Women's Studies Librarian, 1993. 100p. Free.

This selective bibliography was first published by Susan Searing in 1988 to "aid colleagues in both designing new gender-centered courses .... [and to] make the history of women in the professions more accessible to practitioners in the various branches of science, medicine, and technology."-Pref. This new edition nearly doubles the size of the first, including citations to more than 2,500 books and periodical articles published through 1992. There are six chapters treating women in the scientific professions, health and biology, home economics/domestic science, technology, children and young adult literature, and a section of general overviews. Each chapter is further subdivided by topic; the chapter on technology, for example, includes sections on 
reference works, individual engineers and technologists, and reproductive technology. Annotations are provided "in cases where titles are not fully expressive of content, or to call attention to specific sections of the work," and an author index allows one to trace the work of specific scholars. The bibliography is free while supplies last and available from the University of Wisconsin System Women's Studies Librarian, 430 Memorial Library, 728 State Street, Madison, Wisconsin 53706. In late January the bibliography will become available via the Internet. For more information, please contact wiswsl@macc.wisc.edu.-S.S.

Huls, Mary Ellen. United States Government Documents on Women 1800-1990: A Comprehensive Bibliography. Westport, Conn.: Greenwood, 1993. 2 vols. $\$ 79.50$ (ISBN 0-313-29016-4). LC 92-38990. Contents: Volume 1: Social Issues; Volume 2: Labor.

Congressional hearings, reports and documents, as well as publications of government agencies and commissions, and other public documents are listed chronologically within broad subject categories in this annotated bibliography. Among the twenty-one topics in the first volume are suffrage and political participation, homemaking and home economics, health, educational equity, divorce and child support, retirement and survivor benefits, violence against women, and female offenders. The chronological arrangement within topics is useful for tracing government activity (or lack thereof) across time. Topics included in Volume 2 range from employment discrimination, affirmative action and pay equity, to war work, the Women's Bureau, and child care and eldercare. Although government documents are relatively easy, if time-consuming, to identify and locate, this cumulative bibliography with its brief annotations, subject arrangement, and topical indexing will considerably help readers seeking material on topics related to women. There are no title or corporate author indexes so this may not be the place to verify an incomplete citation quickly.-S.S.

\section{STATISTICS}

Horn, Robert Victor. Statistical Indicators for the Economic \& Social Sciences. Cambridge and New York: Cambridge Univ. Pr., 1993. 227p. il. \$17.95 (ISBN 0-521-41333-8). LC 92-23005.

This text provides a description of all the major indicators used in the presentation, application, and analysis of statistical data in the social sciences. Although written by an Australian academic, the content focuses on current practice in Britain, North America, and the Western world in general. Considered semantically as metadata, these indicators are the intermediaries that link statistical observations with social or other phenomena; i.e, they bring the data to life.

Initially, the author provides a historical outline of indicators and describes their uses. Following this, the major techniques are explained in detail; included are ratios, scaling, correlation and regression, time series, and multivariate analysis. Each operation is placed in a comparative or historical context as appropriate.

Subsequently the development, economic, and social application of indicators are treated in separate chapters. Development indicators explained are those typically reported by various agencies of the United Nations, the International Monetary Fund, and the World Bank. The economic indicators are those characteristic of the more advanced economies, e.g., measurements of securities and financial markets' activities, business cycles, and international comparisons. Under social applications are included those for health, the environment, culture, war, and peacetime use.

There are no footnotes to the text, but there are references throughout to a substantive bibliography that may be used for expanded reading. Highly recommended for social science collections.- J.L.C.

\section{HISTORY}

Diccionario Biográfico e Histórico de la Revolución Mexicana en el Estado de 
México. Coord. Roberto Blancarte. Zinacantepec: El Colegio Mexiquense; Toluca: Instituto Mexiquense de Cultura, 1992. 298p. il. (ISBN 9686341277$).$ The Diccionario Biográfico e Histórico de la Revolución Mexicana en el Estado de México is an elaboration of one sectionthe section for the state of Mexico- of the seven-volume Diccionario Histórico y Biográfico de la Revolución Mexicana published between 1990-92, in Mexico City by the Instituto Nacional de Estudios Históricos de la Revolución Mexicana. This latter work is a state-by-state inventory of biographical and historical information pertaining to the Mexican Revolution dating from the period 18901920 , including information regarding battles, military campaigns, political groups, official congresses and meetings, publications, laws and legal tracts, political manifestos and popular songs. For each state the arrangement of information is the same: a short historical overview followed by dictionary entries on all the above categories arranged in one alphabetical sequence, and concluding with a chronology of events, a list of governors, a bibliography, and a list of archival repositories.

For the present work, the coordinator of the above project, Roberto Blancarte, has taken the section on the state of Mexico and enhanced it. To locate entries more easily, he has arranged them by categories; he has added illustrations in the form of historical photographs and reproductions of printed documents; and he has expanded coverage to include information about persons who participated in revolutionary activities in the state of Mexico but who were not natives of the state. The result is a well researched, clearly and attractively presented reference tool.

For those Mexican Revolution scholars whose research focuses on the state of Mexico and for those libraries that have little call for a seven-volume definitive biographical and historical dictionary of the Mexican Revolution, the Diccionario biográfico e histórico de la Revolución Mexicana en el Estado de México is a most useful title.-O.d.C.
Encyclopedia of the North American Colonies, Jacob Ernest Cooke, editor-in-chief. New York: Scribner, 1993. 3 vols. $\$ 280$ (ISBN 0-684-19269-1). LC 93-7609.

The editor-in-chief, Ernest Cooke, recognizing that coverage of colonial America has often focused solely on the English colonies, has made a great effort to include the Dutch, Spanish, French, and occasionally Russian ones. Thus in the discussion of taxation, noted scholars write essays on taxation in each: the British, the Spanish borderlands, the French, and the Dutch colonies. The difficulty with the Russian colonies in Alaska and California appears to be the unavailability of source material although there are general articles on the Russian colonies in the Encyclopedia.

The appearance, layout, and arrangement are very similar to Scribner's Encyclopedia of American Social History (see the September 1993 column). The 274 topical and thematic essays by 193 contributors strive to present a "comprehensive coverage and a comparative analysis of the settlements ...., [incorporating] recent changes of scholarly emphasis on the spatial, demographic, cultural, economic and social aspects of the colonial past."-Pref. The essays are arranged within broad topics: The American context, Old World expansion, Colonial settings, Government and law, Economic life, Labor systems, Racial interaction, War and diplomacy, Social fabric, Folkways, Families and the life course, Life of the mind, Science and technology, The arts, Education, Religion, Toward independence. Within a topic, for example under Families and the life course, there are shorter essays, such as Family structure, Sexual mores and behavior, Marriage, Childhood and adolescence, Old age and death, Native American families and life cycles; within these headings separate entries cover the British colonies, the Dutch colonies, the French colonies, and the colonies of the Spanish borderlands. The arrangement is all spelled out in the Table of Contents.

Each article is signed, well-written, has copious cross-references to other essays as well as to maps (there are thirty-two 
maps), and always a bibliography of major studies mostly published within the last twenty years. The index is detailed with "see also" references, and the larger headings are broken down by subheadings; the major articles are identified by boldface type and the tables by italic type. The Chronology runs from 985 and Erik the Red to 1867 when Russia sold its North American possessions. The list of contributors includes the titles of the articles that each wrote.

And how does this work compare with The Encyclopedia of Colonial and Revolutionary America. John Mark Faragher, general editor (New York: Facts on File, [1990]. 484p.)? The Faragher has an emphasis on the English colonies, has short articles, has maps and portraits, only occasional bibliographies at the ends of the articles, and a subject index. There are "Topic Guides" which accompany major articles in order to identify shorter articles related to them; for example, the topic guide with the article for Frontier lists about thirtyfive general articles and thirty biographical entries.

For ready reference the Faragher would be a quicker starting point but for in-depth research, scholars will be very glad to have Cooke's Encyclopedia of the North American Colonies.-E.M.

Epstein, Catherine. APast Renewed: ACata$\log$ of German-Speaking Refugee Historians in the United States after 1933. Publications of the German Historical Institute. Cambridge and New York: Cambridge Univ. Pr., 1993.386p. \$54.95 (ISBN 052144063-7). LC 92-568.

Catherine Epstein has compiled a biobibliography of "historians of modern Europe ...., historians of Jewish and other religions' histories, historians of economics and law, historians of medicine, and historians of Oriental and ancient people" (Introd.) who emigrated to the United States between 1933 and 1940 from one of the German-speaking parts of Central Europe. To be included these scholars must have received formal training and have embarked on a career in Germany or the Austro-Hungarian
Empire, taught history after their arrival in the United States, and have enough information available for Epstein to be able to reconstruct their careers.

For each scholar brief biographical information is given (birth, death, year of emigration, citizenship, education, professional work), a bibliography of works by the subject and also works about him (only five women appear), references to any published bibliographies for the person, and a note locating the archives.

Appendixes give a bibliography of general works on German-speaking refugee historians and a discussion of the historians for which little data can be found. The topical index is carefully done with boldface type for the individual entries; it includes references for the institutions with which the subjects were affiliated either in Europe or the United States.

This compilation will be extremely useful, of course, to the historiographer but also for the student just looking for biographical information on an author.E.M.

Favier, Jean. Dictionnaire de la France Médiévale. Paris: Fayard, 1993. 982p. 750 FF (ISBN 2-213-03139-8).

This dictionary of medieval France is based on Jean Favier's considerable erudition as a scholar and archivist. He is the director of the Archives Nationales and author of a number of books for specialists and for general readers. The dictionary covers some ten centuries of the history of the French people, roughly spanning from the fourth to fifteenth centuries. Here the geographic boundaries are of secondary importance: from England to the Middle East, whether it be a crusade or the house of Lusignan in Cyprus, the book will take us wherever the French were active.

Concise and informative articles cover all aspects of medieval French society from the Church and the royal government systems to daily life such as clothing items and food. Each article ranges from a few lines to more than ten pages. The author omits on purpose any bibliography that he considers to have a lim- 
ited utility because it would become obsolete rather quickly and most people are unlikely to have access to a specialized research collection. Good cross-references are throughout. Attractively illustrated with numerous monochrome photographs and thirty-two pages of color plates.-J.S.

Historical Atlas of the Middle East. G. S. P. Freeman-Grenville. New York: Simon \& Schuster, 1993.144 p. $30 \mathrm{~cm}$. \$55 (ISBN 0-13-390915-8). LC 93-9294/map.

There are surprisingly few up-to-date historical atlases of the Middle East. Some are more like picture books than atlases, others are limited to Biblical or Islamic history. The Historical Atlas of the Middle East is, therefore, a welcome addition to any collection of historical atlases in school and home libraries.

The work is intended for the general reader but would serve well for college libraries. Arranged chronologically, the 113 maps cover the period from earliest historical times to the present and treat the Middle East in the context of the Mediterranean world and beyond, ranging from Spain and Morocco to Afghanistan. One of the maps presents the percentage of Muslims in the total population for the countries of the world.

The information is presented in double-page spreads with maps on the righthand pages in shades of gray and green accompanied by commentaries on the left pages which summarize the historical background. With a detailed table of contents, bibliography, and an index which includes cross-references to variant place names, it will prove very useful for scholars and for students.-J.S.

Slavic Studies: A Guide to Bibliographies, Encyclopedias, and Handbooks. Compiled and edited by Murlin Croucher. Wilmington, Del.: Scholarly Resources, 1993. 2 vols. (986p.) $\$ 150$ (ISBN 0-8420-2374-7). LC 92-28912.

This impressive survey of more than 5,200 reference sources for the study of Slavic countries and cultures is clearly destined to become a classic. Reflecting many years of work, it lists major bibli- ographies, catalogs, directories, dictionaries, encyclopedias, gazetteers, handbooks, and various other reference works in English, French, German, and the Slavic languages. All works were examined by the author, and most entries include useful annotations concerning contents and the place of a work in the broader context of reference sources.

Two initial sections entitled "Area Studies" and "Eastern Europe and the Balkans" include works that treat the region as a whole (the first including the former Soviet Union, the second excluding it). Then follow individual sections devoted to Bulgaria, the former Czechoslovakia, Poland, the former Soviet Union, and the former Yugoslavia. At the end is a listing of general reference works that contain important material of relevance to Slavic studies, followed by author and subject indexes.

Croucher has done an outstanding job of assembling the key reference works in the field. Inevitably, as with any bibliography of this kind, each user will find one or two additional titles that she or he might have included. This reviewer, for example, would have added Alfonsas Ššlaukis's Lituanica Collections in European Research Libraries: A Bibliography (Suppl. DC162), Christoph Schmidt's Ausgewählte Bibliographien und Bibliothekskatalog zur russischen Sozialgeschichte, 1861-1917 (see March 1993 column), and the eight-volume Słownik Starožytnošci SYowian'skich (Wroclaw: Ossolineum, 1961-91), although only the last of these omissions could be described as a major oversight.

A more serious problem is the complicated arrangement of entries, which are filed in alphabetical order of subject headings within each country chapter, much as in a card catalog and, within a given heading, in a kind of chronological order that is not always easy to follow. This, combined with an absence of cross references in the text or index, makes the work somewhat difficult to scan and hinders quick look-ups of known items. A reader looking for the Polish literary bibliography, perhaps best known as "Nowy Korbut" (Guide 
BD1304) for example, will not find it under that entry in the index even though the work is included in the bibliography. A user scanning the Lithuanian entries in the former Soviet Union section could easily miss Patricia Grimsted's Archives and Manuscript Repositories in the USSR: Estonia, Latvia, Lithuania, and Belorussia (Guide AB155), since it is listed elsewhere as a multitopic work, and no cross-reference is provided.

In short, to make the best use of this work, one must study it carefully, but the result is sure to be rewarding for scholars seeking to identify the tools needed to begin their research or to chase down a particular citation. It is likewise certain to prove a valuable tool for librarians in assessing the completeness of their Slavic reference holdings.

A work of this high quality and comprehensiveness invites comparisons with Paul Horecky's standard bibliographies of basic publications for Russian, East Central European, and Southeast European studies (Guide DC530, DC25, DC26 respectively). Like those works, it belongs in every library supporting research relating to the Slavic field, even ones without extensive Slavic collections of their own.-R.H.S.

\section{NEW EDITIONS AND SUPPLEMENTS}

The fifth edition of the Columbia Encyclopedia, edited by Barbara A. Chernow and George A. Vallasi (New York: Columbia Univ. Pr.; sold and distributed by Houghton Mifflin, [1993]. 3048p., \$99; 4 th ed., 1975, Guide AC9) has been updated to late 1992. The publisher estimates that 40 percent of the articles are revised. So a cursory look reveals that Bill Clinton and the Commonwealth of Independent States have entries; Kleistel, the new president of Austria, is there but not Vranitzky, who has the more important post of prime minister; population figures are updated to 1990; the card catalog and the library entries are the same as in the fourth edition with no mention of the impact of computers; the article on Russia stops with the formation of the USSR. "See" and "see also" references abound as do the bibliographies of book titles at the end of many of the articles. And finally the illustrations are very clear and well placed, mostly line drawings, maps, and charts.

The Chicago Manual of Style: The Essential Guide for Authors, Editors, and Publishers has been thoroughly revised (14th ed., John Grossman, managing editor. Chicago: Univ. of Chicago Pr., 1993, 921p., \$40; 13th ed., 1982. Guide AA425) particularly to note the "role of computers in nearly every aspect of publishing beginning with the preparation of manuscripts .... and continuing through editing, designing, typesetting, indexing and printing" (Pref.). Other changes include the increase in the number of examples, the heavily rewritten chapters on documentation, and the chapter on copyrights and permissions "which has been thoroughly revised by William Strong to reflect the most recent law and the most sensible current procedures."

The fourth edition of African Books in Print, edited by Hans M. Zell (London: Hans Zell, 1993, 2 vols., 1520p., $\$ 400$, 3d ed., 1984, Guide AA603) lists 23,186 titles in English, French, or African languages "in print as of the end of 1991 from 745 publishers and research institutions with publishing programs in 45 African countries" (Introd.). These titles come from the list of books in the third edition. (1984) still in print, a cumulation of all titles in volumes 9-17 (1983-91) of African Book Publishing Record (Guide AA602), and new records received directly from the publisher. Excluded are government publications and serials (but not annuals, yearbooks, and irregular series).

The third cumulative index for volumes 1-35 of Swedish Imprints 1731-1833: A Retrospective National Bibliography (Uppsala: Dahlia Books, 1993. Unpaged; for the set see Guide AA1113) supersedes the indexes for volumes 1-15 and volumes 1-20. It provides indexing for main entries, added entries, including dedicatees, engravers, printing, publishing and bookselling firms, and for year and first word. The supplementary entries are addenda and corrigenda. 
The second volume of James E. Walsh's Catalogue of Fifteenth-Century Printed Books in the Harvard University Library (Binghampton, N.Y.: Medieval and Renaissance Texts and Studies, 1993. 672p., 16pl. Medieval \& Renaissance Texts \& Studies, 97, \$50) covers books printed in Rome and Venice and is indexed by author/title, by individual editor and translator, by provenance, and has a concordance for Hain/Proctor/Gesamtkatalog/Goff numbers (see Guide AA269-AA273, AA275, AA278AA279). Volume 1 (1991) describes fifteenth-century books published in Germany, German-speaking Switzerland, and Austria-Hungary.

With its thirty-second edition, Ulrich's International Periodicals Directory (New York: Bowker, 1993.5 vols., \$395; for earlier editions see Guide AE10) is taking its first step toward worldwide newspaper coverage. Volume 5 of the set lists 7,000 daily and weekly newspapers published in the United States; it has its own index. Other changes in this edition of Ulrich's are the addition of flags to indicate titles registered with the Copyright Clearance Center, notations for titles available through document delivery from six services, and pointers for journals available exclusively online or in both forms: online as well as paper.

The third edition of the World Encyclopedia of Library and Information Services, edited by Robert Wedgeworth (Chicago: ALA, 1993. 905p., \$200; 1st ed., 1980, Guide AB32; 2d ed., 1986, Suppl. AB11), maintains both the objectives and the scope of the two previous editions - to present a "one-volume overview of the history, major institutions and the distinguished personalities that have shaped the field" of librarianship (Pref.). Articles have been updated and revised and others added to reflect contemporary issues, e.g., cutting-edge technologies, new political realities (changes in Eastern Europe and the former Soviet Union were addressed but because of the unsettled nature of the area the attempt could only be partially successful). A large number of photos and charts, many of them new, as well as a sixteen- page color-photo section do much to enhance the visual appeal of the text.

New editions of three guides to library collections have appeared this year: World Directory of Map Collections, compiled by the IFLA Section of Geography and Map Libraries, edited by Lorraine Dubreuil (3d ed., Munich: Saur, 1993, 310p., IFLA Publications $63 £ 35$; $2 d$ ed. 1976, Guide CL303) which now lists 522 collections from 67 countries that have more than 1,000 maps; that is, unless it's the national library or archives or the only map collection in the country and these are included. SCOLMA Directory of Libraries and Special Collections on Africa in the United Kingdom and in Europe, compiled and edited by Tom French (5th rev. and exp. ed. New York and London: Hans Zell, 1993. 355p., \$85; 4th ed., 1983, Guide DD45) is expanded to include the countries of Eastern Europe. The Researcher's Guide to British Film \& Television Collections, edited by James Ballantyne (4th rev. ed., London: British Universities Film \& Video Council, 1993. 226p., $£ 12.50$; 3d ed. 1989, 2d ed. 1985, Suppl. BG84) now describes 246 collections, including some not open to the public; for example, most of the BBC libraries are included because they are discussed in other guides even though the use is restricted. The Appendix has a directory for the Republic of Ireland and a selected bibliography which includes a section listing relevant Parliamentary Papers.

Also recently issued are several revisions of archival guides: The Second World War: A Guide to the Public Record Office, 2 d ed., edited by John D. Cantwell (London: PRO, 1993. 218p., £10.95; 1st ed., 1972, Guide DA209) adds coverage of additional files which have been opened since early 1972; and the Directory of Irish Archives, edited by Seamus Helferty and Raymond Refaussé (Blackrock, County Dublin: Irish Academic Pr., 1993. 154p. £24.95; 1st ed., 1988) which has grown from 150 to 224 entries for libraries and archives in the Republic and in Northern Ireland.

The third edition of the Directory of Religious Organizations in the United States, compiled by J. Gordon Melton 
(Detroit: Gale, 1993. 728p., \$125; 2d ed., 1982 , Guide BB68) has grown to 2,500 entries for religious groups, e.g., "relevant for-profit organizations such as religious publishers and consultants, ... . academic and historical organizations, social service agencies, groups engaged in social protest and change, centers nurturing spiritual life, ... denominational archives and historical offices" (Pref.) but not "offices of Christian and denominational bodies covered in the Encyclopedia of American Religions [1989, Suppl. BB30]." Also omitted are social service organizations that serve only one community.

A related title is the Encyclopedia of African American Religions, edited by Larry G. Murphy, J. Gordon Melton, and Gary L. Ward (New York: Garland, 1993. 926p., \$125), which provides entries for 1,200 African American religious leaders, denominations, and other organizations and movements with attention to the political impact of the Civil Rights Movement, the status and role of women, and the role of slavery in the development of religious life. The longer articles are signed and have bibliographical notes. It is well indexed with subject/organization/personal name entries and with a cross-index of all biographical entries by church or religious tradition with which a person is identified.

The Handbook of the Linguistic Atlas of the Middle and South Atlantic States, edited by William A. Kretzschmar and others (Chicago: Univ. of Chicago Pr., 1993, 454 p., \$45) proposes to "help users of the research materials of LAMSAS [Guide BC93] to judge the material accurately and appropriately ... [by discussing] the history of the project and the aims of its designers, the communities and informants and how information was collected from them, and about several editorial stages in the processing of the information ..... [with] also a few comments about interpretation" (Pref.).

The Linguistic Atlas of Early Medieval English begins with a Catalogue of Sources (Cambridge: D. S. Brewer, 1993, 186p. \$53), compiled by Margaret Laing. It "aims to list all the potential sources for LAEME, that is, any surviving text written down in English between ca. 1150 and 1300 .... [It can also serve] as a useful reference book for any study of English at this period whether its prime concerns be linguistic, textual, literary or historical" (Introd.). The arrangement is by repository and the annotation includes references to indexes, anthologies, further editions, other studies, and published facsimiles.

Richard Combs and Nancy R. Owen have revised the 1971 Authors: Critical and Biographical References, $2 \mathrm{~d}$ ed. Metuchen, N.J.: Scarecrow, 1993. 478p., $\$ 49.50 ; 1$ st ed. 1971, Guide BD116). They have increased the number of authors from 1,400 to 3,317 and the number of books analyzed from 500 to 1,158 titles.

Literatur Lexikon: Autoren und Werke deutsche Sprache, edited by Walther Killy, is now complete in fifteen volumes (Güttersloh and Munich: Bertelsmann, 198893. 15 vols., $2520 \mathrm{DM}$ ). Volumes $1-12$ treat German-speaking authors and anonymous titles, while volumes 13-14 concentrate on themes, methodology, movements such as humanism, farce, psychoanalysis and literature, and the Weimar Republic. The last volume is an index for personal names, anonymous titles, and topics.

Another German set now complete is the second edition of Gerhard Dunnhaupt's Personalbibliographien zu den Drucken des Barock (Stuttgart: Hiersemann, 1990-93. 6 vols. 4723 p. 2000 DM per volume). This set provides a bibliography of original writings and translations for 200 major German seventeenth-century authors. Volume 6 completes the alphabet and has the indexes: name, pseudonym, publisher, anonymous title, place of publication, and topic.

The New Princeton Encyclopedia of Poetry and Poetics, edited by Alex Preminger and T. V. F. Brogan (Princeton, N.J.: Princeton Univ. Pr., 1993. 1383p., \$125) has totally revised the enlarged edition (1974, Guide. BD314) adding "all those movements in recent criticism and literary theory that bear on poetry, ... . [as well as] increased coverage of emergent and non-Western poetry" (Pref.). The 
bibliography has been much updated, there are more cross-references, and the editors have labored for a very clear prose style.

Coverage of the period $1625-1700$ is now complete for the Index of English Literary Manuscripts, compiled by Peter Beal, with the volume for Nathaniel Lee-William Wycherley (London: Mansell, 1993. 672p. \$500; for other parts of the title which have been published, see Guide BD546). Beal states that he hopes to issue an index for $1450-1700$ with sections for titles, first lines of poems, personal names, manuscripts by location and which will also include supplementary entries and information gained since 1980 .

The Concise Companion to Classical Literature (Oxford and New York: Oxford Univ. Pr., 1993. 575p., \$18.95) is really a revised and abridged version of the $O x$ ford Companion to Classical Literature edition of 1989 (Suppl. BD366) shortened by about one-third by omitting a few obscure mythological figures, "dropping or radically shortening the long general entries that are not specific to literature-such as agriculture, architecture, and army - and by recasting in pithier form those on the history, political and topographical background" (Pref.).

Geoffrey Parker, editor of the fourth edition of the Times Atlas of World History (London: Times Books; Maplewood, N.J.: Hammond, 1993. 360p., 37cm., \$95; 3d ed., 1989, Suppl. DA30) has examined all the maps with particular attention to the prehistoric and post-1945 sections. Also revised is the twelve-page chronology which now covers from around 9000 B.C. to 1991-92.

Contrary to the usual practice, the latest cumulative index for the National Union Catalog of Manuscript Collections (Guide DA64) covers only four years, 1986 through 1990 (Hamden, Conn.: Shoe String, 1992.597p.) because in 1986 a national database of archives and manuscripts was begun on RLIN. Thus we should all keep the 1985 annual index. NUC-MC has broadened its definition and now covers oral histories, sound recordings, audiotapes, paintings, video recordings, playbills, and screenplays.
Slavery and Slaving in World History: A Bibliography, 1900-1991, compiled by Joseph C. Miller (Millwood, N.Y.: Kraus, 1993, 576p., \$90) is a major updating. The 19,351 entries are double that of the 1983 edition of 5,117 entries and more than six times as extensive as the 1977 (Guide CC381) which had 1,645. The bibliography now includes "secondary, scholarly works, written from the perspective of any academic discipline, reflecting directly on slavery or on the slave trade anywhere in the world and published in a Western European language, ... substantial reviews and review essays, unpublished conference papers, encyclopedia articles of more than routine significance, articles in scholarly periodicals, popular history magazines, and serious journalism, chapters in multi-authored, edited collections, and books and monographs, translations and reprints. ..." (Introd.).

Barry Klein's Reference Encyclopedia of the American Indian now in its sixth edition (West Nyack, N.Y.: Todd Publications, 1993. 679p., $\$ 125 ; 5$ th ed. 1990 ,

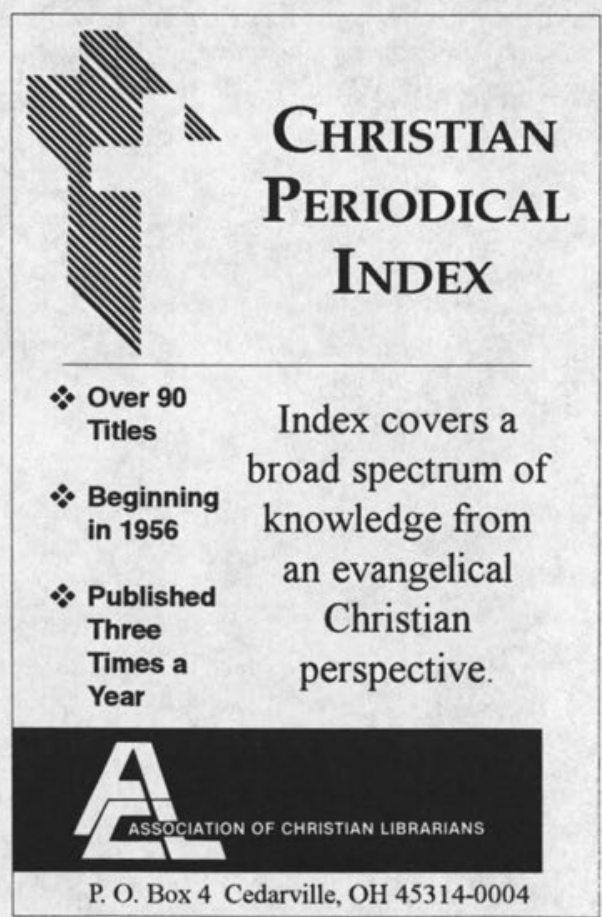


Suppl. CC226) is in four parts: (1) Source listings, which is a directory of relevant organizations, agencies, tribal authorities, etc., with a new chapter on arts and crafts shops and cooperatives; (2) Canadian listings; (3) bibliography of approximately 4,500 books in print presented by broad topics with a publishers index; (4) biographical sketches of 2,500 important Native and non-Native Americans prominent in Indian affairs, business, arts, professions, history.

Lionel V. Lorona is again editing the supplement to Gropp's A Bibliography of Latin American Bibliographies (Guide AA77), this time the fifth, for bibliographies published 1985-89 (Metuchen: Scarecrow, 1993. 314p., \$39.50) plus a few items missed in the earlier supplements. This volume is arranged by broad topics subdivided by country with subject and author indexes and includes a list of serial titles cited/examined.

Scarecrow Press has begun another series of dictionaries of the history of a country: European Historical Dictionaries and they are leading from strength with Volume 1: Historical Dictionary of Portugal by Douglas L. Wheeler (Metuchen, N.J.:
1993. 288p., \$37.50). Wheeler covers all facets of Portuguese history up to about 1990 with articles mostly about individuals, places, organizations, including a few longer survey articles under such topics as colonial empire or relations with other countries. But the real joy is the very extensive bibliography of Portuguese and English materials.

The New Encyclopedia of Archaeological Excavations in the Holy Land, edited by Ephraim Stern (New York: Simon \& Schuster, 1993. 4 vols., 1552p., \$295; 1st ed., 1976-78, Guide BB187) updates the coverage of the sites to 1991 and adds new ones, with signed articles by scholars, a bibliography, and an index of people and places. The Stern encyclopedia is, of course, the source for discussion of specific sites. For interpretation and extrapolation, one reference to which the reader will turn is the Archaeological Encyclopedia of the Holy Land, edited by Avraham Negev, $3 d$ ed. (New York: Prentice Hall, 1990, 419p.; 1st ed. 1972, Guide BB188) for its articles on daily life, culture, technology, etc. Unfortunately Negev is not indexed nor does it have any bibliography. 